\title{
PERKAWINAN SEJENIS DALAM KONSTRUKSI \\ TEORI MASHLAHAH
}

\author{
Oleh. Fajar \\ Institut Agama Islam Negeri (IAIN) Bone \\ Email: fajarphilosophy@gmail.com
}

\begin{abstract}
This study uses the Mashlahah approach in explaining the similar legal position of marriage. Based on the consideration of the maslahah by paying attention to the objectives of Islamic law, which is to withdraw maslahah and reject mudharat, similar marriage is in fact contrary to the purpose of the fourth Islamic law, namely raising offspring. Therefore, Islam strictly prohibits marriage not only because it is against the Shari'a, but also contrary to the nature of humans who tend to live in pairs, precisely tend to the opposite sex.

Similar marriage or similar sex (homosexual) is a deviant behavior that is very cruel and transcending, which is beyond the limits of the divine will of human nature. Then similar marriage is forbidden in Islam because it not only has a negative impact on the individual, but also ruining community life. Because the reluctance of marriage to the opposite sex is just the same as destroying the survival of humans on the earth, because it has become a sunnatullah that it is impossible to create a generation of humans from same-sex marriage. So the logic of marriage in Islam is with the opposite sex (heterosexual) and not the same sex marriage (homosexual) that justifies liwat.
\end{abstract}

\section{Keywords: Similar Marriage; Sexuality; Maslahah.}

\section{Abstrak}

Kajian ini menggunakan pendekatan Mashlahah dalam menjelaskan kedudukan hukum perkawinan sejenis. Berdasarkan pertimbangan mashlahah dengan memperhatikan tujuan hukum Islam, yaitu menarik maslahat dan menolak kemudharatan, perkawinan sejenis secara nyata bertentangan dengan tujuan hukum Islam yang ke empat, yaitu memelihara keturunan. Oleh karena itu, Islam melarang keras perkawinan sejenis bukan hanya karena bertentangan dengan syariat, namun juga bertentangan dengan fitrah manusia yang cenderung hidup berpasang-pasangan, tepatnya cenderung kepada lawan jenis.

Perkawinan sejenis ataupun hubungan seks sejenis (homoseks) merupakan perilaku menyimpang yang amat keji dan melampaui batas, yaitu melampaui batas-batas kehendak suci fitrah manusia. Maka perkawinan sejenis diharamkan dalam Islam karena bukan hanya membawa dampak negatif terhadap individu, melainkan juga merusak sendi-sendi bangunan masyarakat. Karena keengganan kawin dengan lawan jenis sama saja menghancurkan keberlangsungan hidup manusia di muka bumi, karena sudah menjadi sunnatullah bahwa tidak mungkin bisa lahir generasi manusia dari perkawinan sesama jenis. Maka logika perkawinan dalam Islam adalah dengan lawan jenis (heteroseks) dan bukannya perkawinan sesama jenis kelamin (homoseks) yang menghalalkan liwat.

Kata Kunci: Perkawinan Sejenis; Seksualitas; Maslahah. 


\section{A. Pendahuluan}

Membangun perkawinan bukan hanya sekedar membangun peran sebagai suami ataupun istri. Melainkan perkawinan memiliki tujuan yang lebih mulia daripada itu. Karena perkawinan adalah sebuah ikatan suci yang bertujuan untuk menjaga kesucian fitrah manusia sebagai makhluk cenderung hidup berpasangpasangan. Perkawinan merupakan institusi sosial yang telah melalui perkembangan budaya manusia. Melalui perkawinan manusia menciptakan rumah tangga, tujuannya tidak hanya untuk melanjutkan keturunan melainkan untuk menjaga kemuliaan dan kehormatan manusia dalam menjalani perannya di muka bumi. Untuk itulah Allah Swt, mengatur perkawinan dalam syariatnya yang suci untuk mengendalikan hawa nafsu manusia agar tidak jatuh ke dalam kubang perzinahan dan perilaku seks yang menyimpang.

Sebagai seorang muslim, tentu kita semua paham bahwa perkawinan, disamping menjaga kemuliaan manusia juga menjauhkan manusia dari perilaku yang dapat merusak tatanan masyarakat seperti perilaku seks bebas, perzinahan, dan perilaku seks yang melampaui batas fitrah manusia semisal homoseksualitas. Yaitu kecenderuangan seks pada sesama jenis. Islam menghalalkan Perkawinan dan mengharamkan perilaku zina, apatalagi perilaku seks sesama jenis (homoseks). Islam menjunjung tinggi pemuliaan hidup manusia, sehingga Islam hanya mentolerir hubungan seks dalam batas-batas yang dibenarkan syariat, disamping mengarahkan kehendak seks manusia.

Dalam hal ini, seks adalah hak eksintesial yang mesti diaktualkan, dalam artian setiap manusia memiliki hak atas kenikmatan seks. Karena secara hakikat manusia cenderung hidup berpasang-pasangan, tepatnya cederung kapada lawan jenis. Kecenderungan pada lawan jenis dan kenikmatan seks itu bukan hasil konstruksi yang dipengaruhi oleh faktor-faktor sosial dan budaya, melainkan ia melekat pada hakikat diri manusia secara fitrah. Dari kecenderungan itulah masyarakat membentuk institusi perkawinan untuk memenuhi kehendak fitri manusia atas seks. Sehingga dikatakan, seks bukan tawaran melainkan hak yang mesti dipenuhi dan dialami.

Namun bukan berarti seks bisa dilakukan tanpa memperhatikan batasan dan kemaslahatan manusia. Islam mengatur secara tegas seks yang diperbolehkan 
dan seks yang tidak diperbolehkan, termasuk perkwinan yang boleh dan tidak boleh. Sudah menjadi pemahaman umum bahwa logika perkawinan dalam Islam adalah dengan lawan jenis (heteroseks) dan melarang keras perkawinan sesama jenis kelamin (homoseks). Kajian ini menggunakan pendekatan Mashlahah, untuk menjelaskan perkawinan sejenis secara argumentatif, yaitu menguraikan pertimbangan dari sisi maslahat dan mafsadat untuk menentukan kedudukan hukumnya.

\section{B. Pembahasan}

\section{Konsep Perkawinan dalam Islam}

Makna perkwinan secara bahasa penggabungan atau percampuran antara pria dan wanita. Sedangkan secara istilah syariat, adalah akad antara pihak pria dengan wali wanita, sehinggga hubungan badan antara pria dan wanita menjadi halal. ${ }^{1}$ Dengan demikian, perkawinan ialah akad yang menghalalkan pergaulan dan membatasi hak dan kewajiban serta tolong-menolong antara seorang laki-laki dan seorang perempuan yang bukan mahram. ${ }^{2}$ Allah berfirman dalam QS. alNisa': (3);

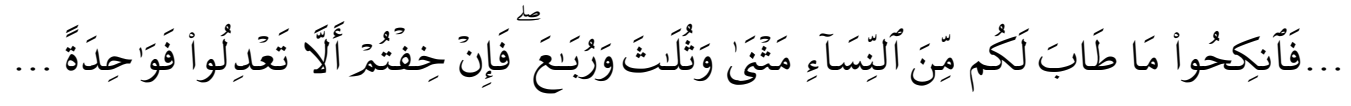

Terjemahnya:“...Maka kawinilah wanita-wanita (lain) yang kamu senangi : dua, tiga atau empat. kemudian jika kamu takut tidak akan dapat Berlaku adil, Maka (kawinilah) seorang saja..."

Perkawinan merupakan jalan untuk membina sebuah rumah tangga, serta melahirkan keturunan sesuai dengan jalan hidup manusia yang mulia. Kehidupan dan keberlanjutan peradaban umat manusia sangat bergantung dengan adanya perkawinan dari perjalanan sejarah generasi umat manusia. Karena secara hakikat manusia adalah makhluk sosial yang cenderung hidup berpasang-pasangan dalam ikatan perkawinan antara laki-laki dan perempuan.

Telah umum diketahui bahwa salah satu tujuan Perkawinan adalah terciptanya tata kehidupan keluarga bahagia, yaitu keluarga yang di dalamnya terwujud sakinah, mawaddah wa rahmah. Keluarga sakinah hanya bisa terbentuk

\footnotetext{
${ }^{1}$ Hasbi Indra, dkk, Potret Wanita Shalehah, Cet. 3; (Jakarta: Penamadani,2004), h. 72.

${ }^{2}$ Sulaiman Rasjid, Fiqh Islam: Hukum Fiqh Lengkap, (Bandung: Sinar Baru Algesindo, 2013), h. 374.
} 
apabila setiap anggota keluarga berupaya untuk saling menghormati, menyayangi, dan saling mencintai. Itulah fondasi dasar sebuah keluarga. ${ }^{3}$ Allah Swt. menciptakan laki-laki dan perempuan agar dapat berhubungan satu sama lain, salin mencintai, menghasilkan keturunan dan hidup berdampingan secara damai dan sejahtera sesuai perintah Allah Swt. dan petunjuk Rasulullah Saw. ${ }^{4}$ Sebagaimana firman Allah Swt. dalam QS. Al-Ruum: (21);

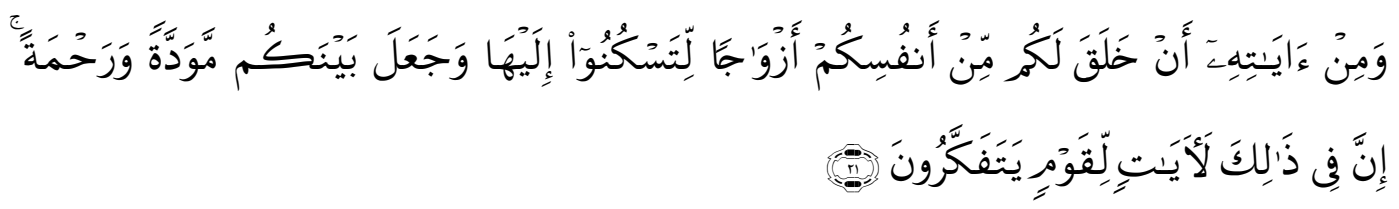

Terjemahnya:"Dan di antara tanda-tanda kekuasaan-Nya ialah Dia menciptakan untukmu isteri-isteri dari jenismu sendiri, supaya kamu cenderung dan merasa tenteram kepadanya, dan dijadikan-Nya diantaramu rasa kasih dan sayang. Sesungguhnya pada yang demikian itu benarbenar terdapat tanda-tanda bagi kaum yang berfikir."

Untuk sampai pada tujuan ini, al-Qur'an menggariskan beberapa prinsip dasar relasi suami dan istri. Di antaranya adalah ikatan pasangan (zawaj) yang setara. Hubungan suami dan istri ibarat sepasang sayap dari seekor burung. Jika sayap yang satu berhenti mengepak, maka terjatuhlah si burung itu. Begitu juga dengan suami dan istri. Al-Qur'an sendiri mengibaratkan hubungan suami istri laksana pakaian (libas). Yang satu adalah pakaian bagi yang lain. Sebagaimana diketahui, pakaian selain berfungsi memberikan perlindungan dari hal-hal yang tidak dikehendaki, juga memberikan keindahan, kehangatan, dan menutupi kerahasiaan dan kekurangan. ${ }^{5}$

Rasulullah Saw. sangat menganjurkan umatnya untuk menikah, dalam sebuah hadis beliau bersabda: "Perkawinan adalah sunnahku, siapa yang benci terhadap sunnahku (tidak mau menikah), maka bukan termasuk umatku.” (HR. Bukhari Muslim). Maka jelaslah sabda Rasulullah Saw. sebelumnya bahwa Perkawinan itu sangat dianjurkan bagi kehidupan umat Islam. Membangun sebuah rumah tangga itu adalah salah satu jalan menuju terjaganya generasi umat

${ }^{3}$ Faqihuddin Abdul Kodir, dkk., Fiqh Anti Trafiking: Jawaban atas Berbagai Kasus Kejahatan Perdagangan dalam Perspektif Hukum Islam, (Cirebon: fahmina-institut, 2006), h. 102.

${ }^{4}$ A. Rahman I. Doi, Penjelasan Lengkap Hukum Allah-Hukum Allah (syariah), (Jakarta: PT. RajaGrafindo Persada, 2002), h. 150.

${ }^{5}$ Faqihuddin Abdul Kodir, Fiqh Anti Trafiking..., h. 103. 
manusia, karena darinya lahir keturunan dan keluarga yang nantinya akan menjadi satuan-satuan dasar dari terbentuknya sebuah masyarakat.

Namun membentuk keluarga itu belum cukup, seorang bapak dan ibu wajib membina keluarga yang berbudi pekerti mulia, yang bermoral dan berakhlakul karimah. Yaitu sebuah keluarga yang dibentuk berdasarkan nilai-nilai dan prinsip-prinsip Islam yang bersumber dari wahyu Allah Swt. dan sunnah Rasul Saw. Inilah yang kemudian disebut sebagai keluarga yang Islami, keluarga yang dibangun di atas pondasi tauhid dan iman yang lurus.

Ajaran Islam yang dibawa oleh Rasul Muhammad saw. sangat menganjurkan umatnya untuk menikah, bagi mereka yang sudah sanggup untuk menjalankannya. Karena melalui lembaga Perkawinan inilah terwujud sebuah rumah tangga atau keluarga yang akan melahirkan generasi manusia dari waktu ke waktu hingga akhir zaman.

Kemudian hal itu telah dipertegas oleh Rasulullah Saw. melalui sabdanya: "Wahai para pemuda, siapa saja diantara kalian telah mampu serta berkeinginan untuk menikah, maka hendaklah menikah. Karena sesungguhnya Perkawinan itu dapat menundukkan pandangan dan memelihara kemaluan. Dan siapa yang tidak mampu kawin, maka hendaklah ia berpuasa, karena sesungguhnya puasa itu dapat menajdi tameng baginya (untuk melemahkan nafsu)." (Mutafaq Alaih).

Sabda Rasulullah Saw. sebelumnya mendorong kaum pria dan wanita untuk segera menikah apabila keinginan untuk menikah itu sudah ada dalam benak mereka. Oleh karena itu Rasulullah Saw. sangat menganjurkan menikah karena dengan menikah antara pria dan wanita dapat menjaga kehormatan dan dapat membentengi diri dari jeratan hawa nafsu yang tak terkendali. Secara fitrah setiap individu yang sehat secara jasmani dan rohani, cenderung untuk hidup berpasang-pasangan dengan lawan jenis. Dalam hal ini menikah dan membina rumah tangga dengan lawan jenis.

Jadi logika Perkawinan di dalam Islam bukan dengan sesama jenis (homoseks), melainkan dengan lawan jenis (heteroseks). Muhammad Hasbi AshShidieqy, menegaskan, "akad nikah tersusun pada lima rukun, yaitu: lelaki; 
perempuan; wali; dua orang saksi; dan lafad akad." Maka tidak sah suatu Perkawinan yang dilakukan dengan sesama jenis kelamin. ${ }^{6}$

Kemampuan seksual yang yang diciptakan pada manusia, laki-laki dan perempuan untuk mencapai tujuan yang mulia yaitu berketurunan, beranak, memperbanyak anak dengan tujuan melanjutkan keturunan generasi manusia. ${ }^{7}$ Berketurunan merupakan hal pokok, oleh karena itu Perkawinan dilakukan. Yang dimaksudkan ialah menjaga keturunan dan melesterikan keberlangsunngan hidup manusia di dunia. ${ }^{8}$ Sebagaimana dinyatakan dalam salah satu tujuan pokok hukum Islam, yaitu melindungi keturunan.

Dengan perkawinan yang sah, kedua belah pihak dapat memperoleh kedamaian, kecintaan, keamanan, dan ikatan kekerabatan. Unsur-unsur ini penting untuk mencapai tujuan perkawinan yang paling besar: ibadah kepada Allah Swt. Ibadah di sini tidak hanya berarti upacara ritual belaka seperti hubungan kelamin suami istri, melainkan mencakup berbagai amal yang baik dalam aspek kehidupan. $^{9}$

Dalam hal ini, secara esensial setiap manusia pada hakikatnya memang terdapat dorongan dan rasa cinta terhadap lawan jenis. Rasa cinta itu sumbernya dari Allah Swt. namun harus diwujudkan melalui jalan yang halal, yaitu melalui proses Perkawinan sesuai yang telah diajarkan oleh Rasulullah Saw. Dengan melalui Perkawinan tersebut, lahirlah sebuah keluarga yang nantinya melahirkan keturunan, yang akan menjadi pelanjut generasi manusia di masa depan. Sehingga Islam mendorong manusia untuk melakukan perkawinan dengan lawan jenis dan mengharamkan perkawinan sesama jenis, seperti yang dilakukan kelompok Gay dan Lesbi atau LGBT yang cenderung menyukai sesama jenis.

Sehingga demikian, dapat dikatakan bahwa Rasulullah Saw. melarang seseorang untuk terus-terus membujang, kecuali dengan beberapa alasan tertentu, misalnya karena penyakit, dan lemah akal. Karena Perkawinan merupakan jalan

\footnotetext{
${ }^{6}$ Tengku Muhammad Hasbi Ash-Shidieqy, Hukum-Hukum Fiqh Islam: Tinjauan antar Mazhab, (Semarang; Pustaka Rizki Putra, 2001), h. 222.

${ }^{7}$ Ali Yusuf as-Subki,Fiqh Keluarga: Pedoman Keluarga dalam Islam, terj. Nur Khozin, (Jakarta; Amzah, 2010), h. 25.

${ }^{8}$ Ali Yusuf as-Subki,Fiqh Keluarga:...h. 24.

${ }^{9}$ A. Rahman I. Doi, Penjelasan Lengkap Hukum Allah.., h. 152.
} 
menuju kesucian dan mencegah dari kubang perzinahan serta hubungan seksulitas yang melamapaui batas fitrah manusia, seperti homoseksualitas yang mempraktikan perilaku seks secara anal (liwat) dan oral.

Allah Swt. memerintahkan umat manusia untuk mengawinkan mereka yang masih sendirian dari golongan pria maupun wanita. Seperti firma-Nya dalam QS. al-Nur: (32);

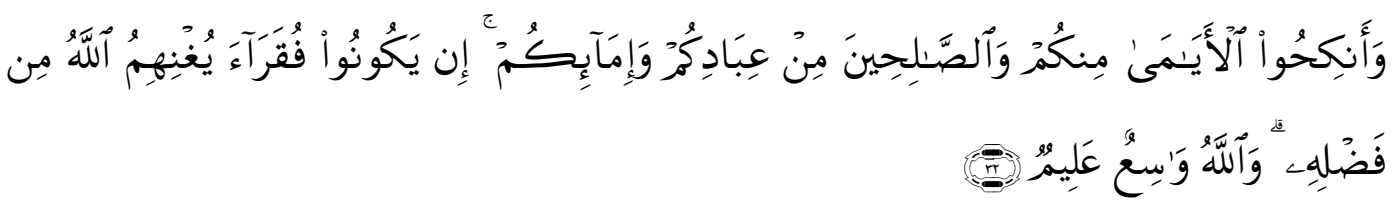

Terjemahnya: "Dan kawinkanlah orang-orang yang sedirian diantara kamu, dan orang-orang yang layak (berkawin) dari hamba-hamba sahayamu yang lelaki dan hamba-hamba sahayamu yang perempuan. jika mereka miskin Allah akan memampukan mereka dengan kurniaNya. dan Allah Maha Luas (pemberian-Nya) lagi Maha mengetahui."

Islam berpendirian tidak ada pelepasan kendali gharizah seksual untuk dilepaskan tanpa batas dan tanpa ikatan. Untuk itulah diharamkannya zina dan seluruh yang membawa kepada perbuatan zina, termasuk larangan hubungan seksual sesama jenis. Tetapi di balik itu Islam juga menentang setiap perasaan yang bertentangan dengan gharizah ini selama masih dalam batas-batas yang dibolehkan agama. Untuk itulah dianjurkan kawin dan melarang hidup membujang dan kebiri. Seorang muslim tidak halal menentang perkawinan dengan anggapan, bahwa hidup membujang itu demi berbakti kepada Allah Swt. padahal dia mampu kawin, atau dengan alasan supaya dan memutuskan hubungan dengan duniawinya. ${ }^{10}$

Rasulullah Saw. memperhatikan bahwa sebagian sahabatnya ada yang kena pengaruh kerahiban ini (tidak mau kawin). Untuk itu maka beliau menerangkan, bahwa sikap semacam itu adalah menentang ajaran Islam dan menyimpang dari sunnah Rasulullah Saw. Justru itu pula, ajaran semacam ini harus diusir jauh-jauh dari masyarakat Islam. ${ }^{11}$

Abu Qilabah mengatakan "Beberapa orang sahabat Nabi bermaksud akan menjauhkan diri dari duniawi dan meninggalkan perempuan (tidak kawin dan

\footnotetext{
${ }^{10}$ Ahmad Sarwat, Fikih Nikah, Cet. I; (Jakarta: Kampus Syariah, 2009), h. 8

${ }^{11}$ Ahmad Sarwat, Fikih Nikah.., h. 9.
} 
tidak menggaulinya) serta akan hidup membujang". Maka berkata Rasulullah Saw. dengan nada marah lantas ia berkata: "Sesungguhnya orang-orang sebelum kamu hancur lantaran berlebih-lebihan, mereka memperketat terhadap diri-diri mereka, oleh karena itu Allah memperketat juga, mereka itu akan tinggal di gereja dan kuil-kuil. Sembahlah Allah dan jangan kamu menyekutukan Dia, berhajilah,berumrahlah dan berlaku luruslah kamu, maka Allah pun akan meluruskan kepadamu”. 12

Selain itu secara filosofis, menikah atau berpasangan itu adalah merupakan ciri dari makhluq hidup. Allah Swt. telah menegaskan bahwa makhluk ciptaanNya ini diciptakan dalam bentuk berpasangan satu sama lain, sebagaimana dalam QS. al-Zariyat : (49);

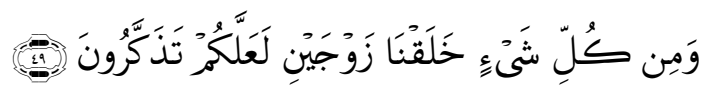

Terjemahnya:"Dan segala sesuatu Kami ciptakan berpasang-pasangan supaya kamu mengingat kebesaran Allah.”

Secara logis ayat di atas ingin menegaskan bahwa sejarah manusia bergerak menuju kesempurnaan bukan karena persamaaan melainkan adanya perbedaan yang terjalin secara dialektis (berlawanan). Salah satunya adalah perbedaan jenis kalamin antara laki-laki dan perempuan membuat peradaban manusia senantiasa eksis dari satu generasi ke generasi yang lain, karena dengannya manusia terdorong untuk melakukan perkawinan dengan tujuan untuk melestarikan manusia dimuka bumi. Karena itu hubungan seksulitas diperintahkan Allah Swt. melalui Perkawinan untuk menyempurnkan kehendak jiwa manusia terhadap lawan jenis.

\section{Seksualitas, Orientasi Seksual, dan Perilaku Seksual}

Sebelum menjelaskan perkawinan sejenis dalam tinjaun teori mashlahah, penting kiranya dijelaskan terlebih-dahulu pemahaman terkait seksualitas, orientasi seksual, dan perilaku seksual. Karena bicara soal perkawinan sejenis tentu tidak lepas dari persoalan seksualitas, termasuk soal orientasi seksual, dan perilaku seksual.

\footnotetext{
${ }^{12}$ Ahmad Sarwat, Fikih Nikah.., h. 9.
} 
Menurut Siti Musdah Mulia sebagaimana dikutip Masthuriyah Sa'dan, Seksualitas adalah bagaimana seorang manusia mendapatkan pengalaman erotis dan mengespresikan dirinya sebagai makhluk seksual, dalam dirinya ada kesadaran diri pribadi sebagai laki-laki atau perempuan, kesadaran tersebut didapat dari kapasitas yang mereka miliki atas pengalaman erotis dan tanggapan atas pengalaman tersebut. Kajian mengenai seksualitas mencakup beberapa aspek, yaitu pembicaraan tentang jenis kelamin biologis (laki-laki dan perempuan), identitas gender, kemudian orientasi seksual dan perilaku seksual.

Identitas gender (jenis kelamin) adalah olahan dari konstruksi sosial yaitu perempuan dengan femininitasnya, laki-laki dengan maskulinitasnya dan transgender yang memiliki kedua-duanya. Pada seseorang yang transgender demikian, ia memiliki dua varian, yakni laki-laki keperempuanan (waria atau banci) dan perempuan kelelaki-lakian. ${ }^{13}$

Lanjut Musdah Mulia dalam Rustam Dahar Karnadi Apollo Harahap, seksualitas adalah sebuah proses sosial yang menciptakan dan mengarahkan hasrat atau birahi manusia (the socially constructed expression of erotic desire), dan dalam realitas sosial, seksualitas dipengaruhi oleh interaksi faktor-faktor biologis, psikologis, sosial, ekonomi, politik, agama dan spiritual. Seksualitas sejatinya merupakan hal yang positif, selalu berhubungan dengan jati diri seseorang, dan juga kejujuran seseorang terhadap dirinya. Studi tentang seksualitas memperkenalkan tiga terminologi penting menyangkut seksualitas manusia, yaitu: identitas gender, orientasi seksual, dan perilaku seksual. ${ }^{14}$

Sedangkan orientasi seksual adalah kapasitas yang dimiliki setiap manusia berkaitan dengan ketertarikan emosi, rasa sayang, dan hubungan seksual. Disebut heteroseksual jika orientasi seksualnya tertuju pada lawan jenis kelamin. Berikutnya, dinamai homoseksual jika orientasi seksualnya sesama jenis kelamin; sesama laki-laki dinamakan gay, sesama perempuan disebut lesbian, dan sesama waria. Biseksual, jika orientasi seksualnya ganda, yaitu seseorang yang tertarik

\footnotetext{
${ }^{13}$ Masthuriyah Sa'dan, "LGBT dalam Perspektif Agama dan HAM", Jurnal NIZHAM, Vol. 5, No. 1, Januari-Juni 2016, h. 17.

${ }^{14}$ Rustam Dahar Karnadi Apollo Harahap, “LGBT di Indonesia: Perspektif Hukum Islam, HAM, Psikologi, dan Pendekatan Mashlahah", Jurnal Al-Ahkam, Volumen 26, Nomor 2, Oktober 2016, h. 230-231.
} 
pada sesama jenis sekaligus juga pada lawan jenis. Sebaliknya, aseksual tidak tertarik pada keduanya, baik sesama maupun lawan jenis. ${ }^{15}$

Perilaku seksual adalah cara seseorang mengespresikan hubungan seksualnya. Menurut Musdah Mulia dalam Masthuriyah, perilaku seksual sangat dipengaruhi oleh konstruksi sosial, ia tidak bersifat kodrati, dan bisa dipelajari. Cara untuk mengespresikan hubungan seksual adalah seperti sodomi atau dalam bahasa Arab disebut dengan liwat. ${ }^{16}$ Sodomi atau liwāt adalah memasukkan alat kelamin laki-laki ke dalam dubur, baik dubur sesama lelaki maupun dubur perempuan. $^{17}$

Untuk itulah Islam mengendalikan seksualitas dengan menetapkan syariat Perkawinanuntuk menjaga kesucian fitrah manusia itu sendiri. Dengan kata lain, salah satu tujuan terpenting ditetapkannya syariat Perkawinan dalam Islam adalah untuk mewujudkan kehendak fitrahwi menusia atasseksagar kehormatan manusia terjaga. Islam mengatur dengan tegas syariat perkawinan dalam batas laki-laki dengan perempuan (heteroseks) dan menolak perkawinan sejenis (homoseks). Sebagaimana firman Allah Swt. dalam QS. Al-Nur: (31);

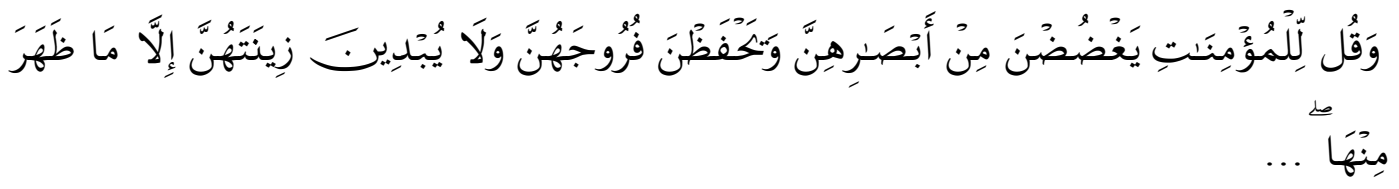

Terjemahnya: "Katakanlah kepada wanita yang beriman: "Hendaklah mereka menahan pandangannya, dan kemaluannya, dan janganlah mereka Menampakkan perhiasannya, kecuali yang (biasa) nampak dari padanya..."

Quraish Shihab dalam Rustam Dahar mengatakan, Perkawinan atau hubungan seks sesama jenis tidak dibenarkan dalam ajaran Islam. Hak asasi manusia yang kerap disuarakan sekelompok masyarakat untuk membela kaum LGBT, Quraish menilai, dalih tersebut tidak bisa dibenarkan begitu saja. Oleh karena itu, ia menilai, menikah atau berhubungan seks dengan sesama jenis telah menjungkirbalikkan hakikat kemanusiaan, dan sanksi Allah Swt. akan datang pada mereka yang mengingkari hakikatnya. Kendati demikian, Quraish

\footnotetext{
${ }^{15}$ Rustam Dahar Karnadi Apollo Harahap, h. 231.

${ }^{16}$ Masthuriyah Sa'dan, “LGBT dalam Perspektif Agama dan HAM”.., h. 18.

${ }^{17}$ Rustam Dahar Karnadi Apollo Harahap, h. 231.
} 
menghimbau agar umat tidak melakukan tindakan sewenang-wenang terhadap kaum LGBT. Sebab, menurut dia, mereka adalah orang yang sedang dijangkiti penyakit dan membutuhkan pertolongan dan pengobatan dari umat. ${ }^{18}$

Secara eksistensial Perkawinan adalah jalan untuk mengaktualkan fitrah manusia akan kehendak dan kecenderungan diri atas kenikmatan seks. Hubungan Seksulitas bukanlah tawaran melainkan keniscayaan yang mesti diaktualkan karena ia bukan kehendak yang lahir dari konstruksi manusia, akan tetapi merupakan kehendak ontologis yang ditetapkan langsung oleh Tuhan melalui proses penciptaan dan kuasanya. Artinya relasi seksualitas adalah hak ontologis yang mendasar dan tak dapat dicabut atau dirampas oleh siapan pun, karena itulah seks mesti dipandang sebagai hak yang mesti diaktualkan untuk meraih kenikmatan darinya.

Relasi seksualitas bukanlah sesuatu yang kotor, melainkan ia adalah panggilan suci Tuhan kepada hambanya, yakni panggilan suci sebagai kehendak fitrahwi menuju kesempurnaan jiwa. Oleh karenanya, seksualitas tidak bisa hanya dipahami sebagai jalan untuk pemuasan tubuh semata, melainkan ia adalah jalan untuk meraih kesempurnaan jiwa secara hakiki di hadapan Allah Swt. Karena di dalam relasi seksualitas manusia akan sampai pada orientasi puncak fitrahwinya, yakni kebahagiaan di dalam hubungan percintaan yang didasarkan atas legitimasi hukum Tuhan. Sebagaimanan firman Allah Swt. QS. Al-Mu'minun : (5-6);

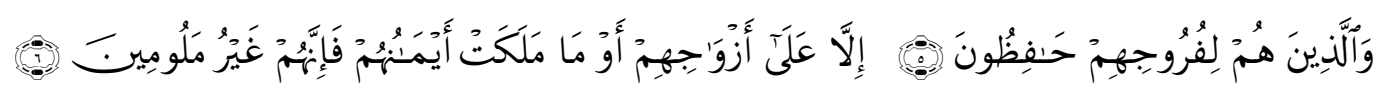

Terjemahnya: dan orang-orang yang menjaga kemaluannya. kecuali terhadap isteri-isteri mereka atau budak yang mereka miliki ${ }^{19}$; Maka Sesungguhnya mereka dalam hal ini tiada terceIa.

Saras Dewi dalam kuliah umum Erotika Kamasutra di Komunitas Salihara, menjelaskan, "Kalau kita merujuk pada teks-teks Hindu, tubuh perempuan ditempatkan pada tempat yang tinggi lagi agung, dimana tubuh perempuan dipandang sebagai "Altar Suci", yakni sebuah wadah untuk

\footnotetext{
${ }^{18}$ Rustam Dahar Karnadi Apollo Harahap, h. 232.

${ }^{19}$ Maksudnya: budak-budak belian yang didapat dalam peperangan dengan orang kafir, bukan budak belian yang didapat di luar peperangan. dalam peperangan dengan orang-orang kafir itu, wanita-wanita yang ditawan biasanya dibagi-bagikan kepada kaum muslimin yang ikut dalam peperangan itu, dan kebiasan ini bukanlah suatu yang diwajibkan. Imam boleh melarang kebiasaan ini. Maksudnya: budak-budak yang dimiliki yang suaminya tidak ikut tertawan bersama-samanya.
} 
melaksanakan ritualitas qurban suci. Qurban suci yang dimaksud disini adalah penyatuan antara dua tubuh, tepatnya adalah relasi seksualitas antara laki-laki dan perempuan. Yaitu sebuah relasi seksualitas yang tidak hanya berhenti pada kepuasan tubuh yang material melainkan seksualitas sebagai gerbang menuju kenikmatan transenden spiritual (Ilahiah). Jadi seksualitas dipahami sebagai jalan pembebasan (Moksa), yang bergerak dari tubuh yang profan menuju tubuh yang sakral". ${ }^{20}$ Artinya relasi seksulitas dibolehkan dalam hubungan Perkawinan, bahkan wajib secara fitrahwi namun dalam batasan antara laki-laki dengan perempuan (bukan dengan sesama jenis-homoseksualitas).

Rasulullah saw. bersabda : "Wahai kaum muda, barang siapa di antara kalian yang sudah memiliki kemampuan seksual, hendaklah kawin. Sesungguhnya yang demikian itu lebih dapat memelihara padangan mata dan kemaluan. Barang siapa yang belum mampu, hendaknya ia berpuasa. Sesungguhnya puasa itu adalah obat baginya." (HR. Bukhari)

Karena itulah, dikatakan, salah satu tujuan perkawinan adalah untuk memenuhi kebutuhan biologis mendasar manusia dalam rangka berketurunan. Adanya keturunan merupakan pernyataan rasa keibuan dan kebapakan. ${ }^{21}$ Rasulullah Saw. melalui sabdanya di atas mengisyaratkan bahwa hubungan seksual merupakan salah satu kebutuhan pokok manusia yang harus terpenuhi. Namun hal tersebut tidak dapat terpenuhi begitu saja tanpa melalui proses yang suci lagi mulia, yaitu Perkawinan. Yaitu Perkawinan yang didasarkan pada kesucian fitrah manusia, Perkawinan antara laki-laki dan perempuan.

\section{Perkawinan Sejenis dari Aspek Mashlahah}

Sudah menjadi suatu keyakinan umum dikalangan alim ulama bahwa tujuan pemberlakuan hukum Islam tiada lain kecuali untuk mewujudkan kemaslahatan bagi manusia. Allah Swt. menghendaki kemaslahatan bagi manusia untuk kebahagian manusia dalam menjalani kehidupan di dunia.

Mashlahah berasal dari kata shalahah dengan penambahan "alif" di awalnya yang secara arti kata berarti "baik" lawan dari kata "buruk" atau "rusak".

${ }^{20}$ Lihat Channel Youtube Komunitas Salihara, Kuliah Umum dan kelas Filsafat "Erotika Kamasutra" yang dibawakan oleh Saras Dewi.

${ }^{21}$ A. Rahman I. Doi, Penjelasan Lengkap Hukum Allah.., h. 153. 
Ia adalah mashdar dengan arti kata shalah yaitu "manfaat" atau "terlepas daripadanya kerusakan". Pengertian mashlahah dalam bahasa Arab berarti “perbuatan-perbuatan yang mendorong kepada kebaikan manusia”. Dalam artinya yang umum adalah segala sesuatu yang bermanfaat bagi manusia, baik dalam arti menarik atau menghasilkan seperti menghasilkan keuntungan atau kesenangan; atau arti menolak atau menghindarkan seperti menolak kemudharatan atau kerusakan. Jadi setiap yang mengandung manfaat disebut mashlahah. Dengan begitu mashlahah itu mengandung dua sisi yaitu menarik atau mendatangkan kemaslahatan dan menolak atau menghindarkan kemudharatan. ${ }^{22}$

Secara terminologi, diartikan dengan mengambil dan menolak kemudharatan dalam rangka memelihara tujuan syara' ${ }^{23}$ Dari definisi tersebut dapat dipahami bahwa kemaslahatan dihubungkan dengan tujuan-tujuan yang ingin dicapai manusia dan jika sesuatu ini bertentangan dengan syara' maka tidak bisa disebut mashlahah.

Definisi di atas sejalan dengan penjelasan Al Ghazali sebagaimana dikutip Amir Syarifuddin, menurut asalnya mashlahah itu berarti sesuatu yang mendatangkan manfaat (keuntungan) dan menjauhkan mudharat (kerusakan), namun hakikat dari mashlahah adalah memelihara tujuan syara' (dalam menetapkan hukum). ${ }^{24}$

Apa yang dimaksudkan Imam al-Ghazali dengan maṣlahah adalah untuk memelihara tujuan syari'at. Adapun tujuan dari syara' meliputi lima dasar pokok, yaitu: 1) Melindungi agama (hifz al-dīn), 2) Melindungi jiwa (hifz alnafs), 3) Melindungi akal (hifz al-'aql), 4) Melindungi keturunan (hifz al-nasab), 5) Melindungi harta benda (hifz al-māl). Semua hal yang dapat melindungi lima kepentingan ini adalah maslahah, dan yang merugikan terpeliharanya kelima hal ini adalah mafsadat, dan menghilangkan hal-hal yang merugikan itu adalah mașlahah. $^{25}$

${ }^{22}$ Amir Syarifuddin, Ushul Fiqh, Ed. I; ( Jakarta: Kencana, 2008), h. 323-324.

${ }^{23}$ M. Alfatih Suryadilaga, "Tujuan Diturunkannya Syari'ah Islam", dalam Dzulmanni, Metodologi Hukum Islam, (Yogyakarta: Teras, 2008), h. 92.

${ }^{24}$ Amir Syarifuddin., Ushul Fiqh, h. 324.

${ }^{25}$ Rustam Dahar Karnadi Apollo Harahap, h. 242. 
Sedangkan Al-Khawarizmi memberikan definisi yang hampir sama di atas, yaitu memelihara tujuan syara' (dalam menetapkan hukum) dengan cara menghindarkan kerusakan dari manusia. ${ }^{26}$

Seluruh hukum yang ditetapkan Allah Swt. atas hamba-Nya, dalam bentuk suruhan atau larangan - adalah mengandung mashlahah. Tidak ada hukum syara' yang sepi dari mashlahah. Seluruh suruhan Allah bagi manusia untuk melakukannya mengandung manfaat untuk dirinya baik secara langsung atau tidak. Manfaat itu ada yang dirasakannya pada waktu itu juga danada yang dirasakan sesudahnya. Umpamanya Allah Swt. menyuruh shalat yang mengandung banyak manfaat, antara lain bagi ketenangan rohani dan kebersihan jasmani. Bagitu pula dengan semua larangan Allah untuk dijauhi manusia. Dibalik larangan itu terkandung kemaslahatan, yaitu terhindarnya manusia dari kebinasaaan atau kerusakan. Umpamanya larangan meminum minuman keras yang akan menghindarkan seseorang dari mabuk yang dapat merusak tubuh, jiwa dan akal. ${ }^{27}$

Artinya hukum dari Allah diadakan untuk kebahagiaan hidup manusia di dunia maupun di akhirat kelak. Sudah menjadi pemahaman umum bahwa secara universal tujuan hidup manusia adalah kebahagiaan. Maka hukum yang ditetapkan Allah semuanya bermuara pada aktualisasi orientasi fitrah manusia, yaitu mewujudkan kebahagiaan yang hakiki bagi manusia itu sendiri. Artinya, tidaklah Allah Swt. memerintahkan untuk berbuat sesuatu kecuali ada kemaslahatan di dalamnya, dan tidaklah Allah Swt. melarang sesuatu kecuali untuk menghidarkan manusia dari kerusakan, sehingga ia selalu berada dalam keadaan maslahat.

Fondasi bangunan syariat Islam itu direpresentasikan oleh maslahah yang ditujukan bagi kepentingan hidup manusia sebagai hamba Allah Swt. baik menyangkut kehidupan duniawinya maupun kehidupan ukhrawi-nya. Syariah Islam itu menjunjung tinggi prinsip-prinsip keadilan ('adâlah), kasih sayang (rahmah), dan mashlahah. Setiap aturan hukum yang menyimpang dari prinsipprinsip tersebut pada hakikatnya bukanlah bagian dari syariah Islam, meskipun dicari rasionalisasi ( $t a$ 'wîl) untuk menjadikannya sebagai bagian dari Syariah

\footnotetext{
${ }^{26}$ Amir Syarifuddin., Ushul Fiqh, h. 324.

${ }^{27}$ Amir Syarifuddin., Ushul Fiqh, h. 322.
} 
Islam. Keagungan dan keluhuran Syariah Islam termanifestasikan pada kompatibilitas hukum-hukum syariah dengan perkembangan kehidupan manusia lantaran ruh mashlahah yang menggerakkannya. ${ }^{28}$

Mewujudkan maslahah merupakan elan vital syariah Islam. Dalam setiap aturan hukumnya, al-Syâri` mentransmisikan mashlahah sehingga lahir kebaikan/ kemanfaatan dan terhindar keburukan/kerusakan, yang pada gilirannya terealisasinya kemakmuran dan kesejahteraan di muka bumi dan kemurnian pengabdian kepada Allah. Sebab, maslahah itu sesungguhnya adalah memelihara dan memperhatikan tujuan-tujuan Syara' berupa kebaikan dan kemanfaatan yang dikehendaki oleh Syara', bukan oleh hawa nafsu manusia. Norma hukum yang dikandung teks-teks Syariah (nusûs al-syarî'ah) pasti dapat mewujudkan mashlahah, sehingga tidak ada mashlahah di luar petunjuk teks Syariah; dan karena itu, tidaklah valid pemikiran yang menyatakan mashlahah harus diprioritaskan bila berlawanan dengan teks Syariah. Maka, mashlahah pada hakikatnya ialah sumbu peredaran dan perubahan hukum Islam, di mana interpretasi atas teks Syariah dapat bertumpu padanya. ${ }^{29}$

Dari uraian di atas, dapat dikatakan, hukum yang ditetapkan Allah Swt. bagi hambanya senantiasa sejalan dengan fitrah dan akal budi manusia. Melalui syariah, kehendak antara Tuhan dan hamba-Nya akan bertemu, yaitu bertemu pada kehendak atas kemaslahatan, yakni Allah Swt. menghendaki kemaslahatan (kebaikan) bagi manusia, demikian tidak ada satu pun manusia di muka bumi ini yang tidak menghendaki kemaslahatan (kebaikan). Secara fitrah jiwa manusia menginginkan kebaikan dan sama sekali tidak menginginkan kerusakan pada dirinya. Maka tepatlah asumsi dan proposisi yang mengatakan: Allah dan hambanya akan bertemu pada kehendak akan kemaslahatan.

Aspek mashlahah menjadi salah satu pertimbangan umum para mujtahid dalam melakukan istimbath hukum apabila tidak ditemukan dalil hukum yang jelas baik dalam al-Qur'an, sunnah Rasulullah Saw. maupun ijma'. Oleh karena itu para ahli hukum Islam menggunakan pendekatanmashlahah dalam h. 1

${ }^{28}$ Salam; Inovasi, Jurnal Filsafat dan Budaya Hukum, Volume 8, Nomor 1, Maret 2011,

\footnotetext{
${ }^{29}$ Salam, h. 316.
} 
menetapkan hukum. Dalam kajian ini pendekatan mashlahah digunakan sebagai dasar analisis dalam memahami dan menjelaskan fenomena Perkawinan sejenis yang akhir-akhir ini banyak diperdebatkan baik di lingkungan akademis maupun di dalam kehidupan sosial.

Secara eksistensial manusia diciptakan secara berpasang-pasangan, yaitu makhluk yang sacara fitrahwi cenderung kepada lawan jenis, cenderung untuk mengaktualkan hasrat seksual dengan lawan jenis. Dalam artian antara laki-laki dan perempuan ada amanah penciptaan di dalam dirinya, yaitu melalui laki dan perempuan Allah mengembangbiakkan manusia untuk keberlanjutan kehidupan manusia di muka bumi. Sebagaimana firman Allah Swt. dalam QS.al-Hujurat(13) dan QS.Al-Nisaa’ (1):

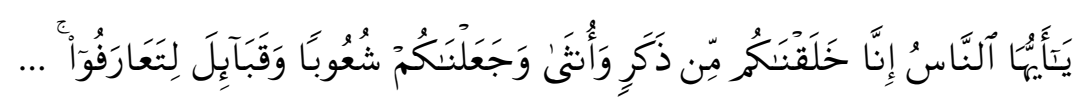

Terjemahnya: Hai manusia, Sesungguhnya Kami menciptakan kamu dari seorang laki-laki dan seorang perempuan dan menjadikan kamu berbangsa bangsa dan bersuku-suku supaya kamu saling kenal-mengenal...

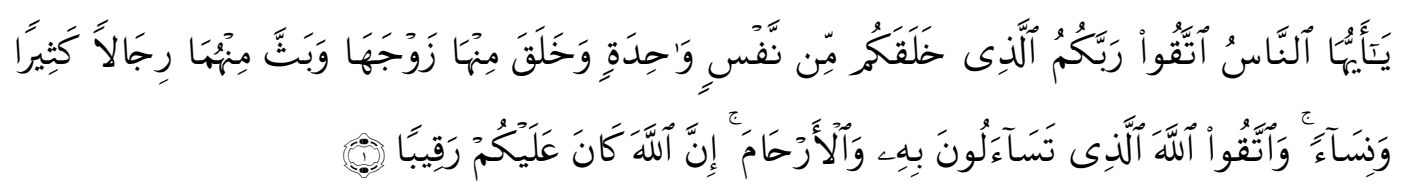

Terjemahnnya: Hai sekalian manusia, bertakwalah kepada Tuhan-mu yang telah menciptakan kamu dari seorang diri, dan dari padanya, Allah menciptakan isterinya; dan dari pada keduanya Allah memperkembang biakkan laki-laki dan perempuan yang banyak. dan bertakwalah kepada Allah yang dengan (mempergunakan) nama-Nya kamu saling meminta satu sama lain, dan (peliharalah) hubungan silaturrahim. Sesungguhnya Allah selalu menjaga dan mengawasi kamu.

Penjelasan normatif ayat al-Qur'an di atas, sejalan dengan fakta empiris bahwa manusia dilahirkan dari seorang laki-laki dan seorang perempuan. Tidaklah lahir seorang manusia kecuali berasal dari seorang laki-laki dan perempuan, maka perkawinan yang sejatinya sejalan dengan sunnatullah adalah perkawinan secara heteroseksual, perkawinan antara laki-laki dan perempuan. Tanpa pertemuan sperma laki-laki dan ovum perempuan maka tak ada manusia yang lahir ke dunia.

Lalu bagaimana Islam memandang fakta perkawinan sejenis? Yaitu Perkawinan antara laki-laki dengan laki-laki dan perkawinan antara perempuan dengan perempuan, perkawinan kaum homoseks. Islam sudah mengatur 
bagaimana fitrah manusia atas seksualitas diwujudkan, ajaran Islam sungguh tidak melarang hubungan seksual. Namun dengan ketetapan hukumnya, Allah Swt. mengatur hubungan seksualitas dalam keridor yang dibolehkan dan tidak diperbolehkan. Tujuannya tentu untuk mewujudkan kemaslahatan manusia, dan demi menjaga keberlanjutan kehidupan manusia di muka bumi.

Homoseks merupakan perbuatan keji dan termasuk dosa besar, yang merusak etika, fitrah, agama, dan jiwa manusia. Homoseks adalah hubungan biologis antara sesama jenis kelamin, baik pria maupun wanita. Namun, istilah homoseks ini kemudian lebih sering dipakai untuk seks sesama pria sedangkan yang sesama wanita dinamakan lesbian.

Homoseks ini dilakukan dengan cara memasukkan zakar ke dalam dubur, sedangkan lesbian dilakukan dengan cara masturbasi satu sama lain, atau cara lainnya, untuk mencapai orgasme (climax of the sex act). Homoseks menyimpang dari fitrah manusia karena fitrah manusia cenderung kepada hubungan biologis secara heterosex, yakni hubungan seks antara pria dan wanita. Perbuatan homoseks bukan hanya terdapat di zaman modern ini, tetapi telah terjadi pada zaman Nabi Luth. ${ }^{30}$

Untuk itulah perkawinan sejenis (homoseks) dihukumi haram dan dilarang keras dalam Islam. Perbuatan tersebut dianggap sebagai perbuatan yang berlebihlebihan dan melampaui batas kawajawajaran. Bahkan dianggap sebagai perbuatan yang amat keji Sebagaiman firman Allah Swt. dalam beberapa ayat barikut:

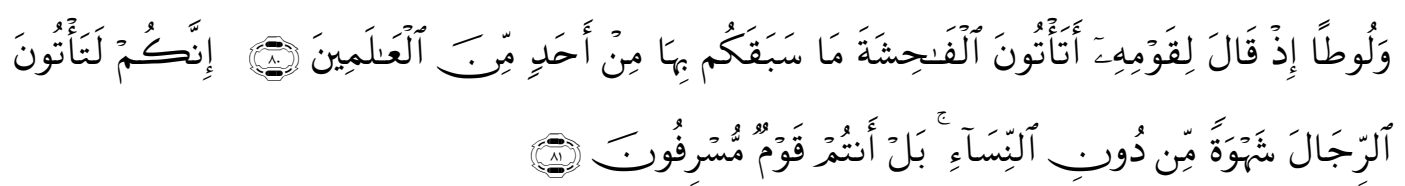

Terjemahnya: dan (kami juga telah mengutus) Luth (kepada kaumnya). (ingatlah) tatkala Dia berkata kepada mereka: "Mengapa kamu mengerjakan perbuatan faahisyah itu, yang belum pernah dikerjakan oleh seorangpun (di dunia ini) sebelummu?" Sesungguhnya kamu mendatangi lelaki untuk melepaskan nafsumu (kepada mereka), bukan kepada wanita, malah kamu ini adalah kaum yang melampaui batas.

\footnotetext{
${ }^{30}$ Ramlan Yusuf Rangkuti, "Homoseksual dalam Perspektif Hukum Islam”, Jurnal Asy-
} Syir'ah, vol. 46, No. 1, Januari-Juni, 2012, h. 194. 


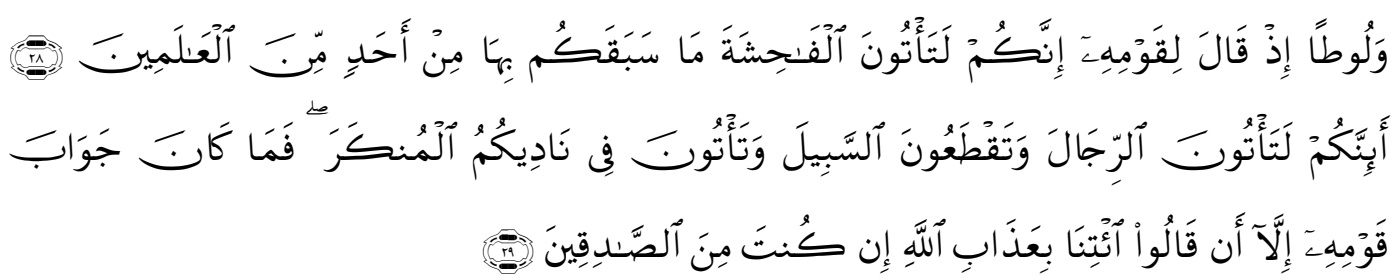

Terjemahnya: dan (ingatlah) ketika Luth berkata pepada kaumnya: "Sesungguhnya kamu benar-benar mengerjakan perbuatan yang Amat keji yang belum pernah dikerjakan oleh seorangpun dari umatumat sebelum kamu". Apakah Sesungguhnya kamu patut mendatangi laki-laki, menyamun dan mengerjakan kemungkaran di tempat-tempat pertemuanmu? Maka jawaban kaumnya tidak lain hanya mengatakan: "Datangkanlah kepada Kami azab Allah, jika kamu Termasuk orang-orang yang benar".

Perkawinan sejenis secara jelas bertentangan dengan tujuan syari' yang ke empat, yaitu menjaga keturunan (hifz al-nasab), maka perilaku seksualitas dengan sesama jenis (homoseksualitas) seperti yang dilakukan kaum LGBT, jelas sangat bertentangan dengan tujuan syar'i yakni menegakkan kemashlahatan, sebab bertentangan dengan fitrah kemanusiaan, bahkan dapat menghancurkan keberlanjutan generasi manusia. Dalam kaidah fikih “al-ḍararu yuzālu”, artinya: "Kemudaratan (bahaya) harus dihilangkan (dihindari). Jadi segala sesuatu yang dapat menimbulkan kerusakan (kemudharatan) maka harus dicegah dan dihindari. $^{31}$

Perilaku perkawinan sejenis selain bertentangan dengan tujuan hukum Islam yang keempat, juga jelas membawa manusia kepada kehancuran karena melawan sunnatullah. Perkawinan dengan sesamajenis kelamin (homoseks), baik yang dilakukan (laki-laki sesama laki-laki) maupun (perempuan sesama perempuan) tentu tidak dapat menjaga mashlahah dari aspek memelihara keturunan. Yaitu memelihara keberlangsungan umat manusia karena perkawinan sejenis (homoseks) jelas tidak akan mendatangkan keturunan.

Oleh karena itu, perbuatan tersebut harus ditolak bukan hanya karena bertentangan dengan hukum Islam, melainkan juga bertentangan dengan kesucian fitrah manusia. Karena asumsi dasar kita, fitrah manusia senantiasa sejalan dengan hukum Islam, begitu pun sebaliknya, hukum Islam senantiasa sejalan dengan fitrah manusia. Maka apa-apa yang dilarang syariat atau hukum Islam tentu hal

\footnotetext{
${ }^{31}$ Rustam Dahar Karnadi Apollo Harahap,..., h. 242.
} 
tersebut mengandung mudharat yang tidak dikehendaki oleh manusia itu sendiri, termasuk dalam hal ini larangan perkawinan sejenis yang biasanya dilakukan oleh kaum homoseksual dari kalangan LGBT karena besarnya mudharat yang ditimbulkan bagi manusia.

Dalam konteks teori mashlahah, menolak kerusakan adalah bagian dari usaha untuk mewujudkan kemaslahatan itu sendiri. Hal ini sesuai dengan kaidah fikih "Daf'ul al-Mafaasid Muqaddamu ala Jalbi al-Mashaalih" Artinya: "Menolak mafsadah didahulukan daripada meraih maslahat". 32

Berdasarkan kaidah di atas, menghindarkan kemudharatan bahaya yang ditimbulkan perkawinan sejenis, dengan jalan melarang aktivitas yang menjurus pada penyimpangan seksual semisal homoseksual (liwat, sodomi-anal seks) adalah suatu keharusan. Bukan hanya karena al-Qur'an dan sunnah Rasulullah Saw. secara jelas melarang hubungan seksual sejenis, akan tetapi besarnya kerusakan (mudharat) yang ditimbulkan. Maka berdasarkan pertimbangan maslahat dan mafsadat, Perkawinan sejenis dilarang karena sama sekali tidak mendatangkan maslahat bagi umat manusia. Jadi Perkawinan sejenis bukan hanya harus ditolak, melainkan harus diberantas atau dihilangkan jalan menuju ke arah tujuan tersebut. Dengan memperbolehkan Perkawinan sejenis, sama saja membuka jalan (wasilah) bagi manusia menuju kerusakan, yaitu menghalalkan hubungan seksual sejenis padahal Allah jelas mengharamkan perbuatan tersebut. Islam tidak mentolerir perkawinan sejenis karena perbuatan itu adalah perbuatan yang teramat keji dan melampaui batas fitrah manusia.

Ibnu Qoyyim al-Jauziyah sebagaimana dikutip A. Djazuli, "segala wasilah yang menuju pada mafsadah harus ditutup jalannya, disebutnya dengan "Sadd alDzari'ah" artinya (menutup jalan), maksudnya menutup jalan kepada yang mafsadah. ${ }^{33}$ Mengacu kepada pertimbangan kemaslahatan dan beberapa kaidah di atas, dapat disimpulkan bahwa Perkawinan sejenis yang mengantarkan pada hubungan seksual dengan sesama jenis kelamin harus dicegah dan dilarang, bahkan harus dihilangkan, karena tidak sesuai dengan hukum Allah Swt. dan tidak

${ }^{32}$ A.Djazuli, Kaidah-Kaidah Fiqih: Kaidah-Kaidah Hukum Islam dalam menyelesaikan Masalah-masalah yang Praktis, Ed. I, Cet. II; (Jakarta: Kencana, 2007), h. 28-29..

${ }^{33}$ A. Djazuli, Kaidah-Kaidah Fiqih:.., h. 30. 
sejalan dengan fitrah manusia yang sejatinya hidup berpasang-pasangan. Syariat Allah memeritahkan manusia untuk melakukan perkawinan dengan lawan jenis, untuk memelihara salah satu tujuan syara' yaitu memelihara keturunan. Maka Perkawinan sejenis jelas tidak mendatangkan faedah bagi manusia, sebaliknya malah mendatangkan mudharat bagi manusia.

Berikut beberapa bentuk mafsadat perkawinan sejenis (homoseks) adalah:

a. Perkawinan sejenis akan menghacurkan kerbelanjutan kehidupan manusia karena perkawinan itu tidak akan mendatangkan keturunan;

b. Perkawinan sejenis akan meruntuhkan sendi-sendi rumah tangga karena keengganan berkawin denganlawan jenis;

c. Menimbulkan penyakit masyarakat berupa hubungan seks sesama jenis yang berakibat pada penyakit kelamin menular berupa sipilis dan aids.

\section{Penutup}

Perkawinan sejenis dalam konteks ajaran Islam, hukumnya jelas, yaitu haram. Perbuatan tersebut dianggap sebagai perbuatan yang melampaui batas dan amat keji, sehingga jalan menuju perbuatan tersebut harus ditutup untuk menghindarkan manusia dari mafsadah atau kerusakan. Menolak kerusakan harus didahulukan daripada mengambil maslahat, tujuannya adalah mempertahankan keberlanjutan kehidupan manusia di muka bumi. Maka satu-satunya perkawinan yang dianjurkan adalah perkawinan dengan lawan jenis untuk menghalalkan hubungan seksual secara heteroseks dan bukannya homoseks. 


\section{DAFTAR PUSTAKA}

A. Djazuli, Kaidah-Kaidah Fiqih: Kaidah-Kaidah Hukum Islam dalam menyelesaikan Masalah-masalah yang Praktis, Ed. I, Cet. Ke-2; Jakarta: Kencana, 2007.

Faqihuddin Abdul Kodir, dkk., Fiqh Anti Trafiking: Jawaban atas Berbagai Kasus Kejahatan Perdagangan dalam Perspektif Hukum Islam, Cirebon: fahmina-institut, 2006.

A. Rahman I. Doi, Penjelasan Lengkap Hukum Allah-Hukum Allah (syariah), Jakarta: PT. RajaGrafindo Persada, 2002.

Hasbi Indra dan Iskandar Ahza Husnani, Potret Wanita Shalehah, Cet.III; Jakarta: Penamadani, 2014.

Tengku Muhammad Hasbi Ash-Shidieqy, Hukum-Hukum Fiqh Islam: Tinjauan antar Mazhab, Semarang: Pustaka Rizki Putra, 2001.

Ali Yusuf as-Subki, Fiqh Keluarga: Pedoman Keluarga dalam Islam, Terj. Nur Khozin, Jakarta: Amzah, 2010.

Ahmad Sarwat, Fikih Nikah, Cet. I; Jakarta: Kampus Syariah, 2009.

Amir Syarifuddin, Ushul Fiqh, Ed. I; Jakarta: Kencana, 2008.

M. Alfatih Suryadilaga, "Tujuan Diturunkannya Syari'ah Islam", dalam Dzulmanni, Metodologi Hukum Islam, Yogyakarta: Teras, 2008.

Rustam Dahar Karnadi Apollo Harahap, "LGBT di Indonesia: Perspektif Hukum Islam, HAM, Psikologi, dan Pendekatan Mashlahah", Jurnal Al-Ahkam, Volumen 26, Nomor 2, Oktober 2016.

Ramlan Yusuf Rangkuti, "Homoseksual dalam Perspektif Hukum Islam”, Jurnal Asy-Syir'ah, vol. 46, No. 1, Januari-Juni, 2012.

Masthuriyah Sa'dan, “LGBT dalam Perspektif Agama dan HAM", Jurnal Nizham, Vol. 05, No. 01 Januari-Juni 2016.

Lihat Channel Youtube Komunitas Salihara, Kuliah Umum dan kelas Filsafat "Erotika Kamasutra" yang dibawakan oleh Saras Dewi. 